\title{
Pelatihan Metode Penelitian untuk Meningkatan Kinerja Guru-Guru SMKN 1 Kota Batu
}

\author{
${ }^{1 *}$ Farida Rahmawati, ${ }^{2}$ Sri Handayani, ${ }^{3}$ Hari Wahyono, ${ }^{4}$ Imam Mukhlis, \\ ${ }^{5}$ Hadi Sumarsono \\ Universitas Negeri Malang; Jalan Semarang 5 Malang \\ "Corresponding author: farida.rahmawati.fe@um.ac.id
}

\begin{abstract}
Abstrak
Salah satu upaya meningkatkan profesionalisme guru adalah dengan meningkatkan intensitas guru dalam melalukan penelitian. Tujuan dilakukan kegiatan pengabdian masyarakat ini adalah untuk meningkatkan kemampuan guru-guru ekonomi dalam bidang penelitian yang berkaitan dengan proses pembelajaran di SMKN 1 Kota Batu. Pelaksanaan kegiatan pengabdian dilakukan melalui dua tahapan kegiatan, yakni tahap penyampaian materi prinsip riset dan tahapanya termasuk aplikasi SPSS, Stata, dan Eviews dan tahap pendampingan penyusunan proposal. Kegiatan pengabdian ini diikuti 25 orang guru. Metode yang digunakan adalah ceramah, diskusi, penugasan, pendampingan dan evaluasi. Hasil kegiatan adalah terdapat peningkatan wawasan dan semangat guru dalam melakukan penelitian bagi kepentingan pembelajaran, keterampilan guru dalam penggunaan aplikasi pengolahan data serta terdapat proposal yang telah layak untuk ditindaklanjuti dalam bentuk penelitian.
\end{abstract}

Kata kunci_Profesionalisme Guru, Pendampingan Pelatihan Metode Penelitian, SMKN 1 Kota Batu

\begin{abstract}
One effort to improve teacher professionalism is to increase the intensity of teachers in conducting research. The purpose of this community service activity is to improve the ability of economic teachers in the field of research related to the learning process at SMK 1 Batu. The implementation of community service activities is carried out through two stages of activities, namely the stage of delivering the material of research principles and the stages including the application of SPSS, Stata, and Eviews and the assistance stage of preparing the proposal. This community service activity was attended by 25 teachers. The methods used are lectures, discussions, assignments, assistance and evaluation. The result of the activity is that there is an increase in teachers' insights and enthusiasm in conducting research for the sake of learning, teacher skills in using data processing applications and there are proposals that have been feasible to be followed up in the form of research.
\end{abstract}

Keywords-Teacher Professionalism, Research Method Training Assistance, SMK 1 Batu

\section{PENDAHULUAN}

$\mathrm{K}$ inerja guru yang profesional merupakan sebuah keharusan bagi pelaksanaan pendidikan di suatu negara guna membentuk manusia berkualitas. Dengan adanya program sertfikasi guru, maka guru dituntut untuk memliliki standar kompetensi yang tinggi. Salah satu hal yang bisa dilakukan untuk mengmbangkan kompetensi guru adalah dengan melakukan kegiatan penelitian. Melalui penelitian, beberapa manfaat akan diperoleh guru, antara lain menambah pengetahuan dan wawasan, memperbaiki kualitas pembelajaran di kelas, meningkatkan kerjasama melalui sistem penelitian kolaboratif, dan sebagainya. Hammersley (1993) mengungkapkan, "educational research should be an integral part of the work of teachers in schools rather than an activity carried out on schools by outsiders". Karenanya, untuk melakukan kegiatan penelitian guru harus memiliki kemampuan berkaitan dengan teknik/metode penelitian. Berbagai macam metode penelitian yang dapat dilakukan seperti metode kuantitatif, metode kualitatif, penelitian tindakan kelas, dan penelitian pengembangan. Usman (2006) menyebutkan bahwa guru yang profesional adalah orang yang terdidik dan terlatih dengan baik, serta 
memiliki pengalaman yang kaya di bidangnya. Selain bertujuan untuk mendukung upaya peningkatan profesionalisme guru, pertimbangan lain yang menjadi dasar pelaksanaan kegiatan pengabdian masyarakat dengan judul "Peningkatan Kinerja GuruGuru SMKN 1 Kota Batu Melalui Pelatihan Metode Penelitian" ini adalah adanya fakta yang menunjukkan rendahnya kualitas dan kuantitas penelitian yang dilakukan oleh para guru. Leonard (2015) dalam penelitiannya yang berjudul "Kompetensi Tenaga Pendidik di Indonesia: Analisis Dampak Rendahnya Kualitas SDM Guru dan Solusi Perbaikannya" memaparkan bahwasanya guru belum memiliki kompetensi yang cukup dalam hal melaksanakan penelitian. Fakta ini terlihat dari hasil studi pendahuluan yang penulis lakukan sebelumnya, yaitu hampir 70 persen guru yang disurvei belum memiliki pengetahuan yang benar mengenai konsep masalah dan penelitian, bahkan hampir 90 persen guru tidak pernah melakukan kegiatan penelitian, dan akhirnya mengakibatkan hampir 100 persen guru tidak pernah melakukan publikasi mengenai hasil penelitian. Kondisi yang sangat memprihatinkan ini berbeda dengan kualitas guru di beberapa negara maju. Chatib (2014) memaparkan bahwa guru menjadi profesi yang sangat menggiurkan di Finlandia, karenanya untuk menjadi gurupun bukanlah hal yang mudah, karena harus berkompetisi dengan ketat.

Terdapat beberapa pertimbangan mengenai pemilihan lokasi pelaksanaan kegiatan pengabdian, diantaranya adalah berdasarkan informasi bahwa SMKN 1 Kota Batu merupakan salah satu sekolah favorit di Kota Batu dengan jumlah siswa yang tergolong dalam kategori sekolah dengan peminat tinggi. Hal ini disebabkan salah satunya adalah karena keuntungan lokasi yang strategis dari SMKN 1 Kota Batu yang berada di pusat kota. Selain itu, sebagai lembaga pendidikan, SMK Negeri 1 Batu memiliki dukungan SDM yang siap untuk berkompetisi dengan sekolah lain dalam pelayanan informasi kepada publik. Adapun tujuan utama dilaksanakannya kegiatan pengabdian masyarakat ini adalah untuk meningkatkan kemampuan guru-guru ekonomi dalam bidang penelitian yang berkaitan dengan proses pembelajaran di SMKN 1 Kota Batu.

\section{METODE}

Metode yang terkait dengan pelaksanaan kegiatan pengabdian kepada masyarakat ini adalah melalui metode ceramah, tanya jawab dan diskusi antara tim pemateri dengan para peserta dan ditutup dengan pendampingan peserta oleh tim pemateri dan mahasiswa pendamping. Lokasi kegiatan pengabdian masyarakat ini adalah SMKN 1 Kota Batu yang beralamatkan di Jalan Bromo No. 11, Sisir, Kecamatan Batu, Kota Batu Provinsi Jawa Timur.Kegiatan pengabdian ini dilaksanakan selama 2 tahap yang terdiri dari pelatihan dan pemaparan materi serta pendampingan penyusunan proposal. Pada tahap pertama dipaparkan materi tentang strategi untuk menumbuhkan jiwa penelitian bagi guru-guru. Setelah itu dilanjutkan dengan materi konsep dasar penelitian. Selain itu, sebelum pendampingan penyusunan proposal, peserta akan dibekali dengan materi tentang metode penelitian.

\section{HASIL DAN PEMBAHASAN}

\section{a. Menumbuhkan Jiwa Peneliti bagi Guru - guru di SMKN 1 Kota Batu}

Materi yang diberikan terkait menumbuhkan jiwa peneliti bagi guru-guru yaitu tentang esensi penting penelitian bagi seorang guru.Sebagai seorang guru harus terus meningkatkan profesionalismenya, salah satunya dengan melakukan penelitian.Pada kegiatan ini, pemateri lebih menekankan kepada upaya agar para guru tertarik untuk melakukan penelitian sehingga bisa meningkatkan kualitas pembelajaran di kelas. Dengan penelitian, guru bisa mengetahui secara pasti upaya apa yang harus dilakukan guna meningkatkan kualitas pembelajaran. Selain itu, para guru juga dijelaskan mengenai jenisjenis penelitian dan bagaimana penerapannya dalam kegiatan pembelajaran.Melalui penjelasan tersebut, diharapkan para guru mempunyai wawasan lebih banyak mengenai metode penelitian, selain penelitian tindakan kelas yang selama ini lebih dominan dikerjakan.

\section{b. Mengenalkan Jenis-Jenis Penelitian dan Implementasinya dalam Kegiatan Pembelajaran di Kelas}

Pada tahap kegiatan ini, dijelaskan mengenai jenis-jenis penelitian, yaitu penelitian kuantitatif, penelitian kualitatif, penelitian pengembangan dan penelitian tindakan kelas. Dijelaskan pula secara rinci mengenai jenis data yang diperlukan, bagaimana memperoleh data-data tersebut serta bagaimana mengolahnya. Ketiga hal tersebut merupakan unsur dasar yang harus ada dalam bab metode penelitian. Berdsarkan hasil pengamatan tim pengabdian, para guru peserta kegiatan relatif lebih lancar dan menguasai dengan tema jenis penelitian tindkana kelas. Hal ini wajar terjadi karena penelitain yang 


\section{Rahmawati dkk. I Jurnal Karinov Vol. 2 No. 3 (2019) 157-160}

selam ini dilakukan oleh padar guru adalah jenis penelitian tindakan kelas. Namun demikian, masih terdapat beberapa pemahaman para guru peserta ynag perlu diluruskan dalam melaksanakan penelitian tindkan kelas tersebut.

\section{c. Pelaksanaan Simulasi Pengolahan Data dengan Menggunakan Aplikasi Program}

Setelah para guru peserta memperoleh penjelasan secara rinci perihal keempat jenis penelitian, maka utnuk mempermudah guru dalam menerapkan konsep tersebut, pemateri menyajikan contoh simulasi pengolahan data penelitian dengan bantuan aplikasi program. Pada tahap kegiatan ini, tim pemateri dibantu secara langsung oleh mahassiwa yang tergabung dalam tim pengabdian. Dipilihnya mahasiswa sebagai pendamping didasarkan pada pertimbangan bahwa mahasiswa tersebut sedang melaksankan penelitian skripsi, sehingga contoh data yang disajikan adalah data riil.Pada tahap ini, para guru peserta menunjuakkan antusiasme yang luar biasa saat mahasiswa memperagakan.Berikut adalah dokumentasi saat guru menerima penjelasan simulasi model pengolahan data melalui aplikasi.

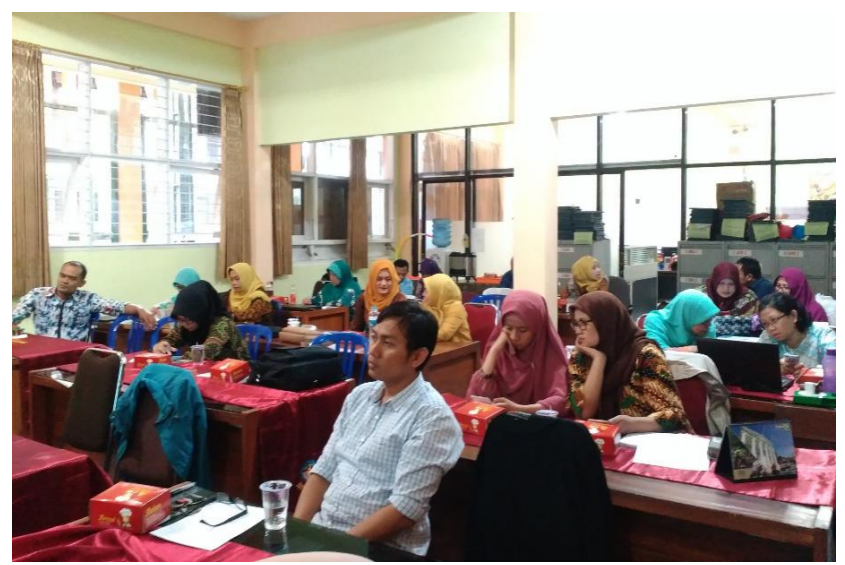

Gambar 1. Peserta Kegiatan Pengabdian Masyarakat

Pada tahap penutup, dilakukan pendampingan tim pengabdian kepada para peserta untuk menyusun proposal penelitian. Melalui kelompok kecil, seluruh peserta berkesempatan untuk mencoba menyusun proposal penelitian dengan didampingi oleh tim. Pendampingan yang dilakukan mulai darai awal, yakni bagiamana merumuskan masalah penelitian, menyusun pertanyaan penelitian, merumuskan tujuan dan manfaat penelitian, melaukan telaah atau kajian teori yang relevan dengan metode peta konsep, menyusun metode penelitian (data apa saja yang diperlukan, bagaimana memperolehnya serta bagaimana menganalsisinya). Dengan pendampingan secara langsung, seluruh peserta diharapakan berani untuk mengeksplorasi seluruh ide dan gagasan terutama terkait dengan permasalahan yang selama ini dihadapi saat melaksanakan kegiatan pembelajaran di kelas. Setelah itu acara dilanjutkan dengan FGD (Focus Group Discussion) tentang Penyusunan Proposal Penelitian. Dalam kegiatan FGD ini ada beberapa guru (peserta) yang mempresentasikan proposal penelitian yang telah dibuat dan akan mendapatkan tanggapan langsung dari Tim Pengabdian. Pada kegiatan FGD ini guru maju dalam mempresentasikan proposal penelitian ada dua guru. Masalah yang diangkat dalam presentasi proposal tersebut yaitu: (1) rendahnya hasil belajar siswa pada mata pelajaran ekonomi, (2) rendahnya motivasi belajar siswa pada mata pelajaran ekonomi. Dalam masalah yang diangkat tersebut diselesaikan dengan menerapkan model pembelajaran yang inovatif. Berikut adalah foto saat pelaksaaan kegiatan pembukaan yang dilakuakn di aula SMKN 1 Kota Batu

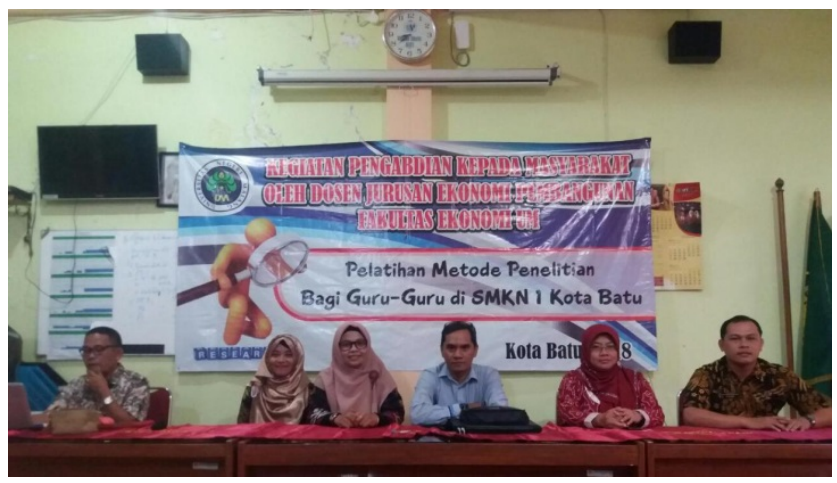

Gambar 2. Tim Pengabdian dan Wakil Kepala Sekolah dalam Acara Pembukaan

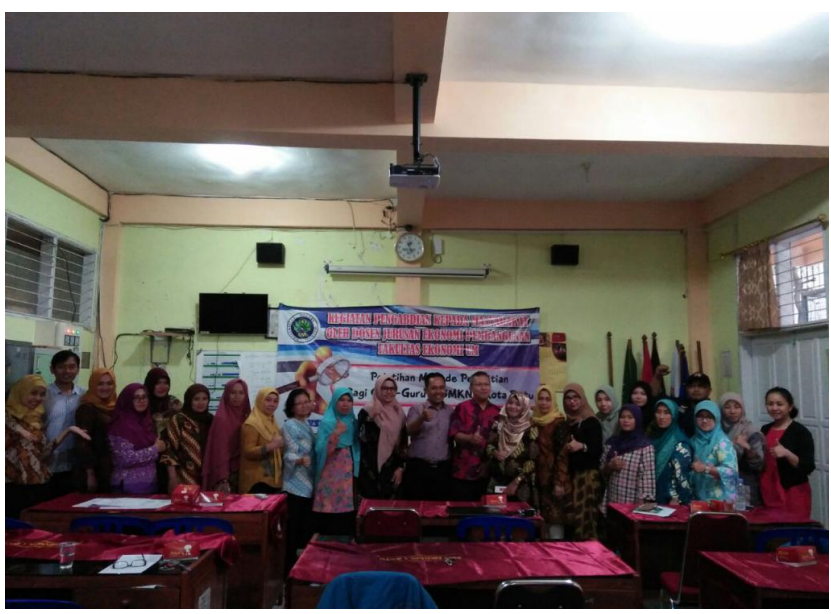

Sumber: dokumen pribadi

Gambar 3. Tim Pengabdian bersama peserta pelatihan 


\section{SIMPULAN}

Penumbuhkan jiwa peneliti pada guru-guru Ekonomi di SMKN 1 Kota Batu dapat dilakukan dengan cara memberikan pendampingan dengan memotivasi agar melakukan penelitian karena untuk menjadi seorang guru profesional harus melakukan kegiatan penelitian untuk meningkatkan kualitas pembelajaran yang dilakukan. Guru hendakanya dikenalkan pada berbagai jenis metode penelitian agar memiliki keberagaman jenis Konsep Penelitian Tindakan Kelas (PTK) bagi guru - guru Ekonomi di Kota Batu yaitu bertujuan untuk mengatasi masalahmasalah pendidikan dan pembelajaran yang terjadi sehari-hari di kelas. Judul PTK hendaknya menggambarkan: masalah yang diteliti, tindakan untuk mengatasi masalah, hasil yang diharapkan, tempat/latar penelitian, secara spesifik.

\section{DAFTAR RUJUKAN}

Chatib, M. (2014). Gurunya Manusia. Bandung: Mizan Pustaka.

Hammersley, M. (1993).On the teacher as researcher. Educational Action Research, 1(3), 425-445.

Ishariwi. (2008). Identifikasi dan Formulasi masalah Dalam Penelitian Tindakan.Makalah Pelatihan PTK Bagi Guru Di Propinsi DIY. Lembaga Penelitian UNY. 2008

Leonard. (2015). Kompetensi Tenaga Pendidik Di Indonesia: Analisis Dampak Rendahnya Kualitas SDM Guru dan Solusi Perbaikannya. Jurnal Formatif, 5(3).

Usman, M. U. (2006). Menjadi Guru Profesional. Bandung: PT. Remaja Rosda Karya 